\title{
Evaluation of ear skin temperature as a cow-side test to predict postpartum calcium status in dairy cows
}

\author{
P. L. Venjakob, ${ }^{*} \dagger$ S. Borchardt, ${ }^{*}$ G. Thiele, $\dagger$ and W. Heuwieser ${ }^{* 1}$ \\ ${ }^{*}$ Clinic for Animal Reproduction, Faculty of Veterinary Medicine, Freie Universität Berlin, Koenigsweg 65, 14163 Berlin, Germany \\ †Veterinary practice $\mathrm{G}$. Thiele, Baruth, Germany
}

\begin{abstract}
Subclinical hypocalcemia is considered a gateway disease that increases susceptibility to other metabolic and infectious diseases in transition dairy cows. In the absence of a cow-side test, however, it is difficult to identify hypocalcemic cows. The objective of this study was to evaluate ear skin temperature as a diagnostic predictor of serum calcium concentration. We conducted a cross-sectional study on 7 commercial dairy farms, involving 251 cows 0 to $48 \mathrm{~h}$ after calving. Skin temperature of the ears (STEar) was scored manually by palpating both ears. An infrared thermometer was used to measure ear temperature, skin temperature on the coxal tuber (STCox), and ambient temperature. Rectal temperature was measured using a digital thermometer. A blood sample was drawn to determine serum calcium concentration. Hypocalcemia was defined as serum calcium below $2.0 \mathrm{mmol} / \mathrm{L}$, irrespective of clinical symptoms. Serum calcium concentration $<2.0 \mathrm{mmol} / \mathrm{L}$ in connection with clinical symptoms was defined as clinical milk fever; serum calcium concentration $<2.0 \mathrm{mmol} / \mathrm{L}$ without clinical symptoms was defined as subclinical hypocalcemia. Multivariate analysis using the GENLINMIXED procedure and receiver operating characteristic analysis were performed to evaluate whether serum calcium concentration could be predicted using ear temperature and other temperature estimates. The prevalence of hypocalcemia was 3.3, $27.3,32.8$, and $69.6 \%$ for cows in first, second, third, and fourth or greater lactation, respectively. None of the cows in first and second lactation had clinical milk fever. The prevalence of clinical milk fever was 6.0 and $20.3 \%$ for cows in their third and fourth or greater lactation, respectively. A decrease in ear temperature of $0.39^{\circ} \mathrm{C}[95 \%$ confidence interval $(\mathrm{CI}): 0.25-0.54]$ was associated with a decrease of $0.1 \mathrm{mmol} / \mathrm{L}$ in serum calcium concentration. Ambient temperature, however,
\end{abstract}

Received December 9, 2015.

Accepted April 5, 2016.

${ }^{1}$ Corresponding author: w.heuwieser@fu-berlin.de was a major confounder for ear temperature. With an increase in ambient temperature of $1^{\circ} \mathrm{C}$, STEar rose by $0.78^{\circ} \mathrm{C}(95 \% \mathrm{CI}: 0.67-0.90)$. Hypothermia was more pronounced in clinical milk fever (median $21.8^{\circ} \mathrm{C}$; interquartile range $14.7-27.0^{\circ} \mathrm{C}$ ) compared with subclinical hypocalcemia (median $27.6^{\circ} \mathrm{C}$, interquartile range $22.1-$ $30.8^{\circ} \mathrm{C}$ ). All temperature estimates had only accurate test characteristics based on their area under the curve for prediction of subclinical hypocalcemia (area under the curve for STEar, STCox, and rectal temperature were $0.641,0.668$, and 0.606 , respectively) when cows with clinical milk fever were excluded. Although ear temperature has been associated with serum calcium concentration, ear temperature cannot be recommended for diagnosis of subclinical hypocalcemia.

Key words: subclinical hypocalcemia, milk fever, ear skin temperature

\section{INTRODUCTION}

Hypocalcemia is a potentially life-threatening metabolic disorder in dairy cows that predisposes them to various other metabolic and infectious disorders (Goff, 2008); it can be clinical or subclinical. Typically, the nadir in blood calcium concentration occurs between 12 and $24 \mathrm{~h}$ after calving, and only blood samples obtained at this time can reveal the extent of hypocalcemia experienced by a dairy herd (Kimura et al., 2006; Goff, 2008). Subclinical hypocalcemia is defined as a concentration of calcium in serum $<2.0 \mathrm{mmol} / \mathrm{L}$ and affects approximately $50 \%$ of animals in second and greater lactation and up to $25 \%$ of animals in first lactation (Reinhardt et al., 2011).

Hypocalcemia around calving is associated with reduced milk yield, increased risk for clinical diseases (e.g., displaced abomasum, metritis) and increased risk of culling in early lactation (Chapinal et al., 2011, 2012a,b; Seifi et al., 2011; Roberts et al., 2012). Subclinical hypocalcemia is more costly than clinical milk fever because it affects a higher percentage of cows in the herd.

Supplementation with oral calcium formulations around the time of calving in cows with subclinical hy- 
pocalcemia can reduce the risk of postpartum problems and increase milk yield (Oetzel, 2013). However, no comprehensively validated cow-side blood calcium test is available to identify cows with subclinical hypocalcemia, except for a hand-held photometric test that has been validated with only 20 samples and described in a preliminary report (Bootz et al., 2014). Known risk factors for hypocalcemia (e.g., parity, high milk yield in previous lactation, lameness) have been recommended as a way of identifying subpopulations of cows in which oral calcium supplementation would be beneficial (Oetzel and Miller, 2012), but this approach may lead to the unnecessary treatment of cows that have risk factors but not hypocalcemia (i.e., false-positive treatment decisions). More importantly, cows that have hypocalcemia but not these risk factors (false negatives) will be missed.

It is well known that decreased temperature of the ear (Guterbock, 2004; Radostits et al., 2007; Peek and Divers, 2008) and skin (Larsen et al., 2001) are clinical symptoms indicative of hypocalcemia in periparturient dairy cows. Therefore, it is common practice for veterinarians and farmers to use ear temperature determined by manual palpation as an estimate for the presence or absence of milk fever (i.e., calcium status) of a periparturient cow. To our knowledge, however, temperature of the ear skin has never been validated as a potential predictor of calcium status.

Infrared thermography allows for the noninvasive measurement of surface skin temperature and does not lead to radiation exposure (Eddy et al., 2001; Schaefer et al., 2004). These characteristics have led to an emerging interest in infrared thermography in both human and veterinarian medicine. The technique has been used previously in cows to assess the skin temperature of the udder and hooves as a way of identifying subclinical mastitis (Colak et al., 2008) and laminitis (Nikkhah et al., 2005), respectively.

Measuring the skin temperature of the ears would be a quick and noninvasive way to assess a cow's calcium status. The objective of our study was to evaluate the diagnostic performance of ear skin temperature in identifying cows with hypocalcemia.

\section{MATERIALS AND METHODS}

The experimental procedures reported herein were conducted with the approval of the Institutional Animal Care and Use Committee of the Freie Universität Berlin. Cows were managed according to the guidelines set by the International Cooperation on Harmonisation of Technical Requirements for Registration of Veterinary Medical Products (Hellmann and Radeloff, 2000)

\section{Cows, Housing, and Feeding}

We conducted a cross-sectional clinical study from January 2015 to August 2015. A convenience sample of 7 commercial dairy farms was recruited within a 165$\mathrm{km}$ radius of a veterinary practice in Brandenburg, Germany. The average herd size was 717 (range 270-1,425). The average milk production (305-d ECM, $4.0 \%$ fat, $3.4 \%$ protein) was $8,766 \mathrm{~kg}$ (range 7,470-9,634 kg). All cows were Holsteins except for herd 3 , in which Jerseys were the dominant breed. Lactating cows were milked twice daily, and for all cows TMR was delivered once daily and pushed up multiple times per day. The TMR from close-up and fresh cows was formulated to meet or exceed minimum nutritional requirements for highproducing dairy cows (NRC, 2001). None of the herds used anionic salts as a prevention strategy for milk fever. Only herd 1 implemented a blanket treatment for cows in third or greater parity, with a fat-coated bolus directly after parturition that consisted of $43 \mathrm{~g}$ of calcium (Bovikalc, Boehringer Ingelheim Pharma GmbH and Co. KG, Ingelheim am Rhein, Germany).

Milking cows in all herds were housed in freestalls. In herds 1, 2, and 4, dry cows were housed in freestall barns with slatted floors and beds equipped with straw (herd 4) or wood shavings (herds 1 and 2). Dry cows in herds $3,5,6$, and 7 were housed in deep straw bedding.

Overall, 251 animals were enrolled. Inclusion criteria were calving within the last $48 \mathrm{~h}$ on a given day (i.e., during a routine herd-health visit).

\section{Experimental Procedures}

Cows were restrained in headlocks during all experimental procedures. All cows enrolled in this study were examined 0 to $48 \mathrm{~h}$ after calving by one veterinarian according to a written standard operating procedure. Briefly, skin temperature of the ears (STEar) was scored manually by palpation of both ears on a 3 -point scale $\left(1=5-15^{\circ} \mathrm{C} ; 2=16-25^{\circ} \mathrm{C} ; 3=26-35^{\circ} \mathrm{C}\right)$. For measuring STEar (Figure 1), we used an infrared thermometer (Fluke 568 IR Thermometer, Fluke Deutschland $\mathrm{GmbH}$, Glottertal, Germany) on the front and rear side of each ear. The device featured a range of -40 to $900^{\circ} \mathrm{C}$, with a resolution of $0.1^{\circ} \mathrm{C}$, a spectral range of 8 to $14 \mu \mathrm{m}$ and a sensitivity of $\pm 1 \%$ or $\pm 1^{\circ} \mathrm{C}$. We used an emissivity of 0.98 as previously described for the skin of calves (Hoffmann et al., 2013), other mammals (Kastberger and Stachl, 2003), and humans (Wolfe and Zissis, 1985).

Temperature was detected with a distance of approximately $1 \mathrm{~m}$ and a measured area of $2 \mathrm{~cm}$ in diameter. Skin temperature on the coxal tuber (STCox) was measured the same way as described for STEar. Rectal 
temperature (RT) was measured using a commercial thermometer (Veterinär-Thermometer SC 12, SCALA Electronic GmbH, Stahnsdorf, Germany).

Temperature of the feeding alley was recorded using the infrared thermometer to obtain an estimate of the ambient temperature.

\section{Blood Sampling and Laboratory Analyses}

Blood samples were taken immediately after evaluation of the skin temperature from the coccygeal vessels using Vacutainer systems (Vacuette $8 \mathrm{~mL} \mathrm{Z}$ Serum Beads Clot Activator, Greiner Bio-One GmbH, Kremsmünster, Austria). Samples were kept at room temperature and allowed to clot. Within $5 \mathrm{~h}$ of blood collection, samples were centrifuged to harvest serum, which was frozen at $-20^{\circ} \mathrm{C}$. Analysis of blood samples was carried out by a commercial laboratory (Synlab Services GmbH, Augsburg, Germany). Total serum calcium concentration was analyzed using photometry (AU680, Beckman Coulter, Krefeld, Germany). The inter- and intraassay coefficients of variation were 1.6 and $0.7 \%$, respectively.

\section{Statistical Analyses}

This study was carried out as an observational experiment. Animals were enrolled by convenience when a veterinarian visited a farm on a given day and an animal met the inclusion criteria of being within $48 \mathrm{~h}$ after parturition.

Individual cow data were transferred to Excel (Office 2010, Microsoft Deutschland Ltd., Munich, Germany). Statistical analyses were performed using SPSS for Windows (version 22.0, SPSS Inc., Ehningen, Germany). The individual cow was the experimental unit in all analyses.

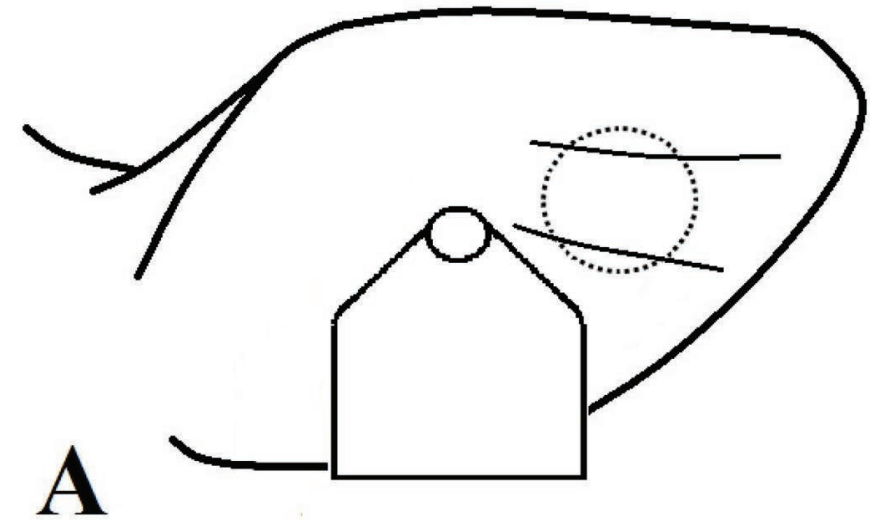

We used univariate analyses to determine the association between calcium status and STEar, STCox, or rectal temperature. Calcium status was defined according to serum calcium concentration and the clinical appearance of the animal. Normocalcemia was defined as a serum calcium concentration greater than or equal to $2.0 \mathrm{mmol} / \mathrm{L}$. Cows not affected clinically with a serum calcium concentration below $2.0 \mathrm{mmol} / \mathrm{L}$ were characterized as having subclinical hypocalcemia. Recumbent cows with a serum calcium concentration below 2.0 $\mathrm{mmol} / \mathrm{L}$ were defined as having clinical milk fever.

Univariate analyses included STEar, STCox, or rectal temperature as dependent variables and calcium status as an independent variable. For evaluation of the association between serum calcium concentration and STEar, STCox, or rectal temperature, we used the GENLINMIXED procedure in SPSS. Herd was considered a random effect. According to the modelbuilding strategies described by Dohoo et al. (2009), each parameter considered for the mixed model should be separately analyzed in a univariate model, including the parameter as a fixed factor (i.e., categorical parameter) or covariate (i.e., continuous parameter). Only parameters resulting in univariate models with $P \leq 0.20$ should be included in the final mixed model. The initial model contained the following explanatory variables as fixed effects: parity $(1,2,3$, or 4 or more), breed (Holstein or Jersey), time after parturition (continuous, 0 to $48 \mathrm{~h}$ ), oral calcium supplementation (yes or no), STEar (continuous), STCox (continuous), and rectal temperature (continuous). We selected the model that best fit the data by finding the model with the lowest value for the Akaike information criterion using a backward elimination procedure that removed all variables with $P>0.10$.

We evaluated the factors that influenced STEar using a GENLINMIXED procedure with STEar as the

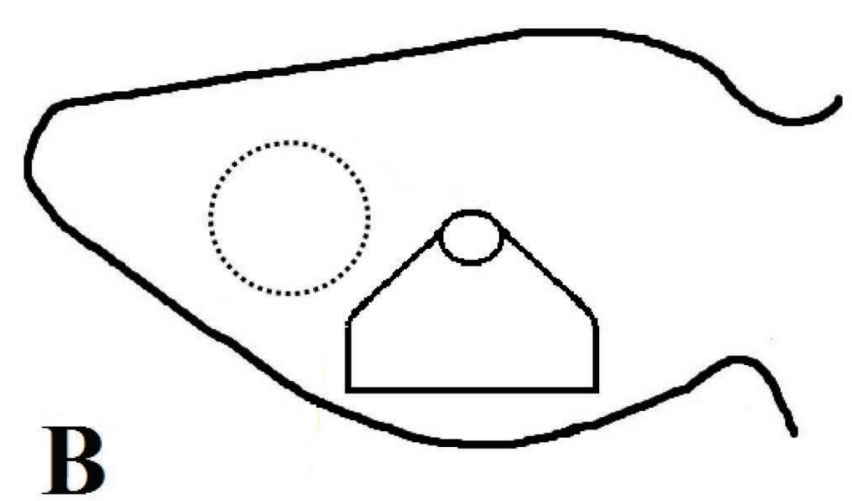

Figure 1. Schematic presentation of the measuring points for the infrared thermometer on the front (A) and rear side (B) of the ear. 
independent variable. We performed model-building and selection of the model that best fit the data as described above. This initial model contained the following explanatory variables as fixed effects: lactation group (1 to 4), breed (Holstein or Jersey), time after parturition (continuous, 0 to $48 \mathrm{~h}$ ), blood calcium (continuous), oral calcium supplementation (yes or no), ambient temperature (continuous), rectal temperature (continuous).

To define reference criteria for identifying cows with subclinical hypocalcemia based on their skin temperature (i.e., STEar, STCox) or rectal temperature, we used a receiver operating characteristic (ROC) analysis. The continuous variable was either skin or rectal temperature, and the classification variable was calcium status. The ROC curves compare sensitivity with 100 - specificity. To differentiate between normocalcemia and hypocalcemia, we used 4 thresholds, which were associated with a negative health or production outcome (Chapinal et al., 2011, 2012a,b; Seifi et al., 2011; Martinez et al., 2012; Roberts et al., 2012). Sensitivity was the proportion of cows diagnosed with hypocalcemia that had serum calcium concentrations below the threshold; specificity was the proportion of cows diagnosed with normocalcemia that had serum calcium concentrations above the threshold (Greiner et al., 2000). The point on the ROC curve with the highest combined sensitivity and specificity was considered the critical threshold. Interpretation of this critical threshold was based on the area under the curve (AUC) according to Swets $(1988)$ as noninformative $(\mathrm{AUC}=0.5)$, accurate $(0.5<$ $\mathrm{AUC} \leq 0.7)$, very accurate $(0.7<\mathrm{AUC} \leq 0.9)$, highly accurate $(0.9<\mathrm{AUC}<1)$, and perfect $(\mathrm{AUC}=1)$.

A significant difference between the levels of a classification variable was declared when $P<0.05$; differences between $P \geq 0.05$ and $P \leq 0.10$ were considered a statistical tendency.

\section{RESULTS}

Data from 251 animals were available for final analysis. Sixty were primiparous cows (23.9\%); 55 (21.9\%), $67(26.7 \%)$, and $69(27.5 \%)$ were in second, third, and fourth or greater lactation, respectively.

The mean interval between calving and investigation of the ear temperature was $19.96 \mathrm{~h}$ (SD 13.91). Overall, the prevalence of subclinical hypocalcemia and clinical milk fever was $27.4 \%(69 / 251)$ and $7.2 \%(18 / 251)$, respectively. The prevalence of hypocalcemia increased with lactation number. Prevalence was $3.3 \%(2 / 60)$, $27.3 \%$ (15/55), $32.8 \%(22 / 67)$, and $69.6 \%(48 / 69)$ for cows in first, second, third, and fourth or greater lactation, respectively. None of the cows in first or second lactation had clinical milk fever. Prevalence of clinical milk fever was $6.0 \%(4 / 67)$ and $20.3 \%(14 / 69)$ for cows in third and fourth or greater lactation, respectively.

As indicated by the multivariate analyses, there was a positive association between each of the 3 animal temperature measures (STEar, STCox, rectal temperature) and serum calcium concentration (Tables 1, 2, and 3). Hypothermia was more pronounced in clinical milk fever compared with subclinical hypocalcemia for STEar (Figure 2, Panel A), STCox (Figure 2, Panel B), and rectal temperature (Figure 2, Panel C), respectively. We analyzed ear skin temperature, STCox, and rectal temperature using ROC curves to determine the critical thresholds (combined highest sensitivity and specificity) for distinguishing between normocalcemia and subclinical hypocalcemia, excluding animals with clinical milk fever (Table 4). The AUC for the differentiation between normocalcemia and subclinical hypocalcemia based on STEar, STCox, and rectal temperature were $0.641,0.668$, and 0.606 , respectively $(P=0.001)$.

Ambient temperature was a potential confounder for STEar (Table 5). However, serum calcium concentra-

Table 1. Association between serum calcium concentration $(\mathrm{mmol} / \mathrm{L})$ and ear skin temperature based on multivariate analysis

\begin{tabular}{|c|c|c|c|c|c|}
\hline \multirow[b]{2}{*}{ Variable $^{1}$} & \multirow{2}{*}{$\begin{array}{c}\text { Estimate, } \\
\mathrm{mmol} / \mathrm{L}\end{array}$} & \multirow[b]{2}{*}{$\mathrm{SE}$} & \multicolumn{2}{|c|}{$95 \% \mathrm{CI}$} & \multirow[b]{2}{*}{$P$-value } \\
\hline & & & Lower CI & Upper CI & \\
\hline Intercept & 1.867 & 0.112 & 1.646 & 2.087 & 0.001 \\
\hline \multicolumn{6}{|l|}{ Lactation group } \\
\hline Lactation 1 & Referent & & & & \\
\hline Lactation 2 & -0.047 & 0.063 & -0.171 & 0.076 & 0.450 \\
\hline Lactation 3 & -0.199 & 0.059 & -0.315 & -0.082 & 0.001 \\
\hline Lactation $4+$ & -0.483 & 0.062 & -0.606 & -0.360 & 0.001 \\
\hline \multicolumn{6}{|l|}{ Breed } \\
\hline Holstein & Referent & & & & \\
\hline Jersey & -0.113 & 0.052 & -0.216 & -0.010 & 0.032 \\
\hline Skin temperature of the ear, ${ }^{\circ} \mathrm{C}$ & 0.012 & 0.003 & 0.005 & 0.019 & 0.001 \\
\hline
\end{tabular}

${ }^{1}$ Model adjusted for the random effect of the herd. 
Table 2. Association between serum calcium concentration $(\mathrm{mmol} / \mathrm{L})$ and skin temperature on the coxal tuber based on multivariate analysis

\begin{tabular}{lccccc}
\hline & & & \multicolumn{2}{c}{$95 \%$ CI } & \\
Variable $^{1}$ & $\begin{array}{c}\text { Estimate, } \\
\text { mmol/L }\end{array}$ & SE & Lower CI & Upper CI & P-value \\
\hline Intercept & 1.379 & 0.312 & 0.764 & 1.994 & 0.001 \\
Lactation group & & & & & \\
$\quad$ Lactation 1 & Referent & & & & \\
Lactation 2 & -0.042 & 0.062 & -0.164 & 0.079 & 0.495 \\
Lactation 3 & -0.200 & 0.058 & -0.315 & -0.085 & 0.001 \\
$\quad$ Lactation 4+ & -0.479 & 0.061 & -0.599 & -0.358 & 0.001 \\
Breed & Referent & & & & \\
$\quad$ Holstein & -0.088 & 0.052 & -0.191 & 0.015 & 0.094 \\
$\quad$ Jersey & 0.027 & 0.006 & 0.015 & 0.038 & 0.001 \\
Skin temperature of the coxal tuber, ${ }^{\circ} \mathrm{C}$ & & & & & \\
\hline
\end{tabular}

${ }^{1}$ Model adjusted for the random effect of the herd.

tion was still associated with STEar when we considered ambient temperature in the same model.

There was a high correlation between STEar and manual ear score $(\mathrm{r}=0.76 ; P=0.001)$. Multivariate analysis indicated an association between manual ear score and serum calcium concentration. Compared with cows with an ear score of 1 , estimated serum calcium concentration was $0.346 \mathrm{mmol} / \mathrm{L}$ (95\% CI: 0.193-0.498; $P=0.001)$ and $0.432 \mathrm{mmol} / \mathrm{L}$ (95\% CI: 0.291-0.573; $P=0.001$ ) higher for cows with ear scores of 2 and 3 , respectively.

\section{DISCUSSION}

It is well known that cows with clinical milk fever have cold extremities (Guterbock, 2004; Radostits et al., 2007). Therefore, many farmers and practitioners implement manual palpation of the ears in fresh-cow protocols to evaluate calcium status and provide calcium supplementation based on this sensorial but subjective observation.
The objective of this study was to evaluate whether this practice might be a useful predictor for identifying not only cows with clinical milk fever but also cows with subclinical hypocalcemia. Hypocalcemia was more prevalent in older cows in our study, which is in agreement with previous results. Reinhardt et al. (2011) showed that serum calcium concentration declined significantly with increasing number of lactations. In the same experiment, the concentration of 1,25-dihydroxyvitamin D $\left[\mathbf{1 , 2 5}\left(\mathbf{O H}_{2}\right) \mathbf{D}\right]$ increased from first to third lactation but plateaued beyond third lactation, which might indicate that endocrine adaptation is inadequate in these cows.

Horst et al. (1990) showed in rats that the concentration of $1,25\left(\mathrm{OH}_{2}\right) \mathrm{D}$ receptors in intestine and bone declined significantly with increasing age. Goff (2014) assumed for dairy cows that the inability to maintain calcium homeostasis was due to the mature skeleton and reduced response to parathyroid hormone in older animals; bone remodeling was reduced, and active osteoclasts and osteoblasts were scarce. It has also been

Table 3. Association between serum calcium concentration $(\mathrm{mmol} / \mathrm{L})$ and rectal temperature based on multivariate analysis

\begin{tabular}{lccccc}
\hline & & \multicolumn{3}{c}{$95 \% \mathrm{CI}$} \\
\cline { 5 - 6 } & $\begin{array}{c}\text { Estimate, } \\
\text { mmol/L }\end{array}$ & $\mathrm{SE}$ & Lower CI & Upper CI & $P$-value \\
\hline Intercept & -3.157 & 1.559 & -6.229 & -0.084 & 0.044 \\
Lactation group & & & & & \\
$\quad$ Lactation 1 & Referent & & & & \\
Lactation 2 & -0.031 & 0.063 & -0.156 & 0.094 & 0.621 \\
Lactation 3 & -0.164 & 0.060 & -0.282 & -0.045 & 0.007 \\
Lactation 4+ & -0.460 & 0.064 & -0.586 & -0.333 & 0.001 \\
Breed & & & & & \\
$\quad$ Holstein & Referent & & & & \\
$\quad$ Jersey & -0.081 & 0.054 & -0.189 & 0.026 & 0.137 \\
Rectal temperature, ${ }^{\circ} \mathrm{C}$ & 0.137 & 0.040 & 0.059 & 0.215 & 0.001 \\
\hline
\end{tabular}

${ }^{1}$ Model adjusted for the random effect of the herd. 
A)

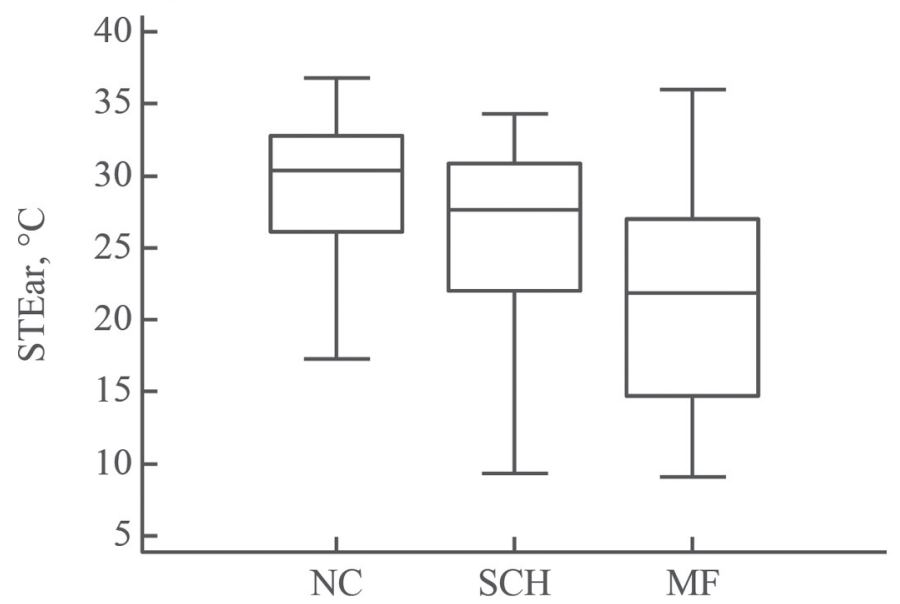

C)

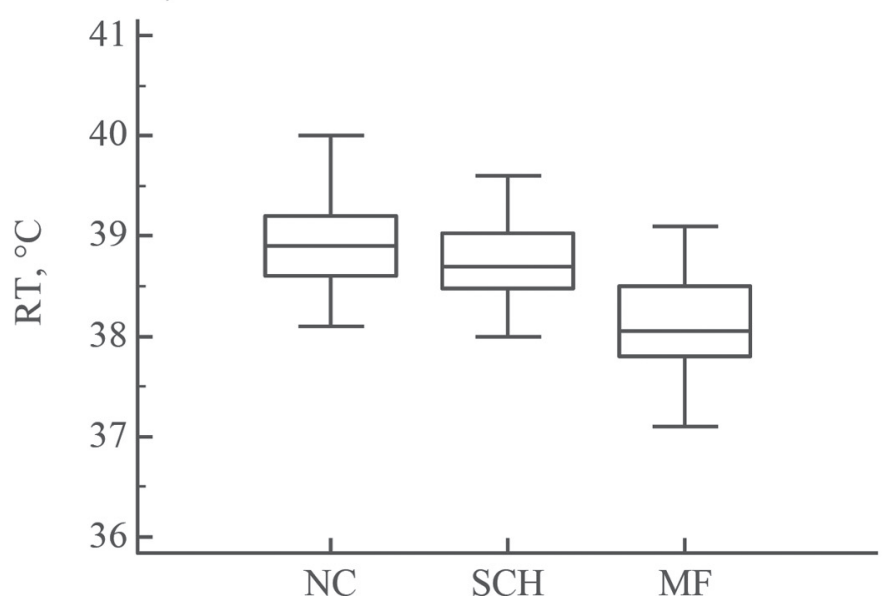

B)

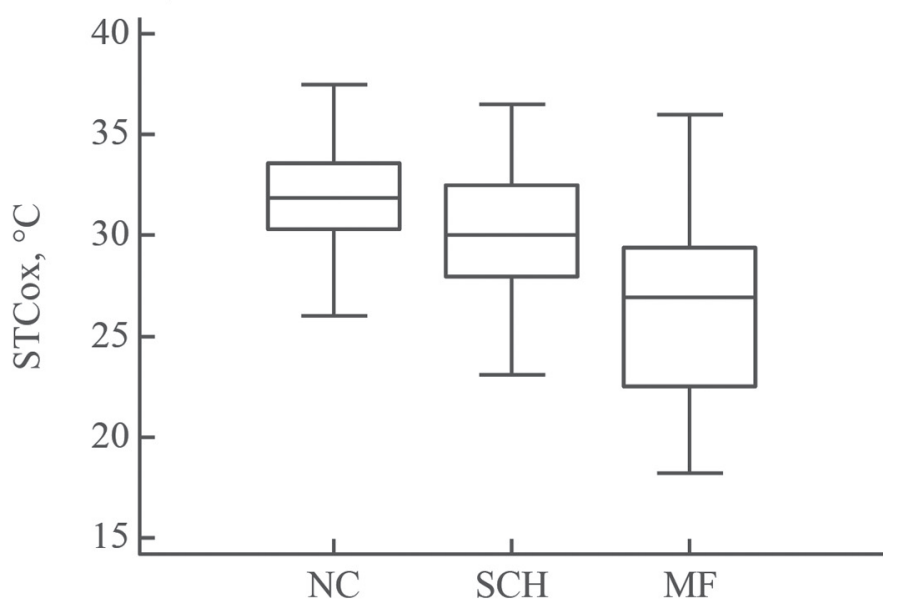

Figure 2. Association between ear skin temperature (STEar; panel A), skin temperature on the coxal tuber (STCox; panel B), rectal temperature (RT; panel C) and calcium status [normocalcemia (NC) $\mathrm{n}=164$; subclinical hypocalcemia $(\mathrm{SCH}) \mathrm{n}=69$; milk fever $(\mathrm{MF}) \mathrm{n}=18]$. The central box represents the interquartile range from the first to third quartile. A segment inside the box shows the highest and lowest case within 1.5 times the interquartile range, respectively.

demonstrated that parathyroid hormone receptors in the kidneys are downregulated with age in rats (Hanai et al., 1990). This might also occur in osteoclasts and osteoblasts of cows, being another reason for maladaptation of mineral metabolism after parturition (Goff, 2014).

Wittek and Jonnson (2011) assumed that postpartum calcium homeostasis and the ability to mobilize calcium might be dependent on immunological processes. They observed a difference in the expression of different immunological profiles of cytokines and chemokines from cows in first lactation compared with cows in a higher lactation. However, further research regarding the role of the immune system in the etiology of hypocalcemia is indicated.
Using multivariate analysis, we compared serum calcium concentrations with temperatures measured on the ear surface, but there was only a moderate relationship between serum calcium concentration and STEar. Hypothermia seemed to be more pronounced in cows with clinical milk fever, but a major confounder was ambient temperature. This finding was consistent with a previous study, which found that the temperature of hooves in horses and cows depended markedly on ambient temperature (Gloster et al., 2011). It was not possible to sample healthy cows under the same environmental conditions as a control group, because a valid cow-side test is not available. Such a comparison might have improved the results of our study. 
Table 4. Critical thresholds for ear skin temperature, skin temperature on the coxal tuber, and rectal temperature to differentiate between normocalcemia and subclinical hypocalcemia based on receiver operating characteristic analyses and considering 4 calcium thresholds to define subclinical hypocalcemia

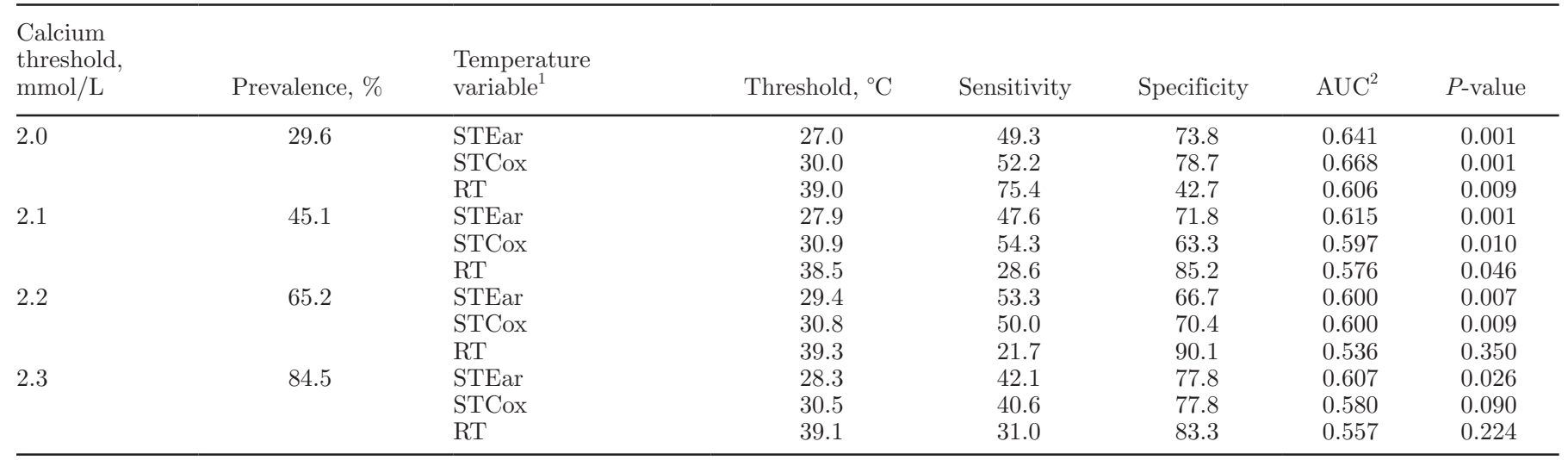

${ }^{1} \mathrm{RT}=$ rectal temperature; STCox $=$ skin temperature on the coxal tuber; STEar $=$ skin temperature on the ear.

${ }^{2} \mathrm{AUC}=$ area under the curve.

Cows with hypocalcemia also had a lower skin surface temperature on the coxal tubers (Radostits et al., 2007) and a lower rectal temperature (Larsen et al., 2001).

Maladaptation of mineral metabolism to periparturient calcium loss via colostrum and milk production leads to calcium deficiency and diminished muscle contraction, finally resulting in recumbency (Goff, 2004). One explanation for the reduced skin and core temperature observed in our study might be this decreased muscle contraction, causing lower thermal energy production. Furthermore, dry matter intake is reduced in periparturient cows (Grummer et al., 2004), which might decrease the heat of fermentation and therefore core temperature.

Another reason for a decreased body temperature is the decrease in serum progesterone concentration around calving (Suthar et al., 2012), which can be used to predict birth in dairy cows (Burfeind et al., 2011).

As stated by Lima and Bakker (2005), sensorial assessment of surface temperature in humans can be used to diagnose reduced peripheral perfusion in shock-like situations. Due to a decrease in cardiac output, clini- cal milk fever might also go along with reduced blood circulation to the extremities and result in colder ears.

The objective of this study was to evaluate whether STEar could be used to identify cows with hypocalcemia, but hypothermia was a poor cow-side predictor for diagnosis of subclinical hypocalcemia, as evidenced by the results from the ROC curve analyses. Hypothermia was more pronounced in cows with clinical milk fever. Therefore, measuring ear temperature has a certain but limited value for determining calcium status. Overall, it cannot be recommended as a diagnostic test for subclinical hypocalcemia. In the absence of a validated cow-side blood test for hypocalcemia, further development and research approaches are warranted to improve the current concept of using risk factors as decision criteria for individual calcium supplementation in fresh cows (Oetzel and Miller, 2012).

\section{ACKNOWLEDGMENTS}

We thank the farm personnel of the dairy farms for the kind cooperation. Furthermore, we thank the staff

Table 5. Association between ear skin temperature and serum calcium concentration considering ambient temperature

\begin{tabular}{|c|c|c|c|c|c|}
\hline \multirow[b]{2}{*}{ Variable $^{1}$} & \multirow[b]{2}{*}{ Estimate, ${ }^{\circ} \mathrm{C}$} & \multirow[b]{2}{*}{$\mathrm{SE}$} & \multicolumn{2}{|c|}{$95 \%$ CI } & \multirow[b]{2}{*}{$P$-value } \\
\hline & & & Lower CI & Upper CI & \\
\hline Intercept & 6.683 & 1.942 & 2.856 & 10.509 & 0.001 \\
\hline Ambient temperature, ${ }^{\circ} \mathrm{C}$ & 0.783 & 0.059 & 0.667 & 0.899 & 0.001 \\
\hline Calcium, mmol/L & 3.918 & 0.734 & 2.472 & 5.364 & 0.001 \\
\hline
\end{tabular}

${ }^{1}$ Model adjusted for the random effect of the herd. 
of the Clinic of Reproduction, Freie Universität (Berlin, Germany) and Michael Kreher for their support.

\section{REFERENCES}

Bootz, F., M. Hostens, and B. Van Ranst. 2014. A new portable blood/urine cow side test for NEFA, calcium, lactate and magnesium. Page 94 in XXVIII World Buiatrics Congress, Cairns, Australia. Australian Veterinary Association, St. Leonards, New South Wales, Australia.

Burfeind, O., V. S. Suthar, R. Voigtsberger, S. Bonk, and W. Heuwieser. 2011. Validity of prepartum changes in vaginal and rectal temperature to predict calving in dairy cows. J. Dairy Sci. 94:5053-5061.

Chapinal, N., M. Carson, T. F. Duffield, M. Capel, S. Godden, M. Overton, J. E. Santos, and S. J. LeBlanc. 2011. The association of serum metabolites with clinical disease during the transition period. J. Dairy Sci. 94:4897-4903.

Chapinal, N., M. E. Carson, S. J. LeBlanc, K. E. Leslie, S. Godden, M. Capel, J. E. Santos, M. W. Overton, and T. F. Duffield. 2012a. The association of serum metabolites in the transition period with milk production and early-lactation reproductive performance. J. Dairy Sci. 95:1301-1309.

Chapinal, N., S. J. Leblanc, M. E. Carson, K. E. Leslie, S. Godden, M. Capel, J. E. Santos, M. W. Overton, and T. F. Duffield. 2012b. Herd-level association of serum metabolites in the transition period with disease, milk production, and early lactation reproductive performance. J. Dairy Sci. 95:5676-5682.

Colak, A., B. Polat, Z. Okumus, M. Kaya, L. E. Yanmaz, and A. Hayirli. 2008. Short communication: Early detection of mastitis using infrared thermography in dairy cows. J. Dairy Sci. 91:4244-4248.

Dohoo, I. R., S. W. Martin, and H. Stryhn. 2009. Veterinary Epidemiologic Research. 2nd ed. University of Prince Edward Island, Charlottetown, PEI, Canada.

Eddy, A. L., L. M. van Hoogmoed, and J. R. Snyder. 2001. Review: The role of thermography in the management of equine lameness. Vet. J. 162:172-181.

Gloster, J., K. Ebert, S. Gubbins, J. Bashiruddin, and D. J. Paton. 2011. Normal variation in thermal radiated temperature in cattle: Implications for foot-and-mouth disease detection. BMC Vet. Res. $7: 73$.

Goff, J. P. 2004. Macromineral disorders of the transition cow. Vet. Clin. North Am. Food Anim. Pract. 20:471-494.

Goff, J. P. 2008. The monitoring, prevention, and treatment of milk fever and subclinical hypocalcemia in dairy cows. Vet. J. 176:50-57.

Goff, J. P. 2014. Calcium and magnesium disorders. Vet. Clin. North Am. Food Anim. Pract. 30:359-381.

Greiner, M., D. Pfeiffer, and R. D. Smith. 2000. Principles and practical application of the receiver operating characteristic analysis for diagnostic tests. Prev. Vet. Med. 45:23-41.

Grummer, R. R., D. G. Mashek, and A. Hayirli. 2004. Dry matter intake and energy balance in the transition period. Vet. Clin. North Am. Food Anim. Pract. 20:447-470.

Guterbock, W. M. 2004. Diagnosis and treatment programs for fresh cows. Vet. Clin. North Am. Food Anim. Pract. 20:605-626.

Hanai, H., D. P. Brennan, L. Cheng, M. E. Goldman, M. Chorev, M. A. Levine, B. Sacktor, and C. T. Liang. 1990. Downregulation of parathyroid hormone receptors in renal membranes from aged rats. Am. J. Physiol. 259:F444-F450.

Hellmann, K., and I. Radeloff. 2000. International Cooperation on Harmonisation of Technical Requirements of Veterinary Medicinal Products (VICH). Brussels/Belgium. Accessed May 3, 2016. http://www.fda.org/downloads/AnimalVeterinary/GuidanceComplianceEnforcement/GuidanceforIndustry/UCM052417.pdf.
Hoffmann, G., M. Schmidt, C. Ammon, S. Rose-Meierhofer, O. Burfeind, W. Heuwieser, and W. Berg. 2013. Monitoring the body temperature of cows and calves using video recordings from an infrared thermography camera. Vet. Res. Commun. 37:91-99.

Horst, R. L., J. P. Goff, and T. A. Reinhardt. 1990. Advancing age results in reduction of intestinal and bone 1,25-dihydroxyvitamin D receptor. Endocrinology 126:1053-1057.

Kastberger, G., and R. Stachl. 2003. Infrared imaging technology and biological applications. Behav. Res. Methods Instrum. Comput. 35:429-439.

Kimura, K., T. A. Reinhardt, and J. P. Goff. 2006. Parturition and hypocalcemia blunts calcium signals in immune cells of dairy cattle. J. Dairy Sci. 89:2588-2595.

Larsen, T., G. Moller, and R. Bellio. 2001. Evaluation of clinical and clinical chemical parameters in periparturient cows. J. Dairy Sci. 84:1749-1758.

Lima, A., and J. Bakker. 2005. Noninvasive monitoring of peripheral perfusion. Intensive Care Med. 31:1316-1326.

Martinez, N., C. A. Risco, F. S. Lima, R. S. Bisinotto, L. F. Greco, E. S. Ribeiro, F. Maunsell, K. Galvao, and J. E. P. Santos. 2012. Evaluation of peripartal calcium status, energetic profile, and neutrophil function in dairy cows at low or high risk in developing uterine disease. J. Dairy Sci. 95:7158-7172.

Nikkhah, A., J. C. Plaizier, M. S. Einarson, R. J. Berry, S. L. Scott, and A. D. Kennedy. 2005. Infrared thermography and visual examination in hooves of dairy cows in two stages of lactation. J. Dairy Sci. 88:2749-2753.

NRC. 2001. Nutrient Requirements of Dairy Cattle. 7th ed. Natl. Acad. Sci., Washington, DC.

Oetzel, G. R. 2013. Oral calcium supplementation in peripartum dairy cows. Vet. Clin. North Am. Food Anim. Pract. 29:447-455.

Oetzel, G. R., and B. E. Miller. 2012. Effect of oral calcium bolus supplementation on early-lactation health and milk yield in commercial dairy herds. J. Dairy Sci. 95:7051-7065.

Peek, S., and T. Divers. 2008. Metabolic diseases. Pages 590-605 in Rebhuns Diseases of Dairy Cattle. T. Divers and S. Peek, ed. Saunders Elsevier, St. Louis, MO.

Radostits, O. M., K. W. Hinchcliff, and P. D. Constable. 2007. Veterinary Medicine. A Textbook of the Diseases of Cattle, Horses, Sheep, Pigs and Goats. 10th ed. W. B. Saunders Company Ltd, London, UK.

Reinhardt, T. A., J. D. Lippolis, B. J. McCluskey, J. P. Goff, and R. L. Horst. 2011. Prevalence of subclinical hypocalcemia in dairy herds. Vet. J. 188:122-124.

Roberts, T., N. Chapinal, S. J. Leblanc, D. F. Kelton, J. Dubuc, and T. F. Duffield. 2012. Metabolic parameters in transition cows as indicators for early-lactation culling risk. J. Dairy Sci. 95:30573063.

Schaefer, A. L., N. Cook, S. V. Tessaro, D. Deregt, G. Desroches, P. L. Dubeski, A. K. W. Tong, and D. L. Godson. 2004. Early detection and prediction of infection using infrared thermography. Can. J. Anim. Sci. 84:73-80.

Seifi, H. A., S. J. Leblanc, K. E. Leslie, and T. F. Duffield. 2011. Metabolic predictors of post-partum disease and culling risk in dairy cattle. Vet. J. 188:216-220.

Suthar, V. S., O. Burfeind, S. Bonk, A. J. Dhami, and W. Heuwieser. 2012. Endogenous and exogenous progesterone influence body temperature in dairy cows. J. Dairy Sci. 95:2381-2389.

Swets, J. A. 1988. Measuring the accuracy of diagnostic systems. Science 240:1285-1293.

Wittek, T., and N. Jonnson. 2011. Gebärparese - Warum erkranken ältere Kühe? - Eine Hypothese. Page 77 in Prophylaxe von Herden- bzw. Produktionskrankheiten. Leipzig, Germany.

Wolfe, W. L., and G. J. Zissis. 1985. The Infrared Handbook. Rev. ed. Office of Naval Research, Department of Navy, Washington, DC. 